\title{
Predictive variables for sleep quality in professional drivers
}

\author{
María-José Serrano-Fernández ${ }^{1}{ }^{2 *}$, Joan Boada-Grau ${ }^{1}$, Lluís Robert-Sentís ${ }^{1}$, and Andreu Vigil-Colet ${ }^{1}$ \\ 1 Faculty of Education Sciences and Psychology. Universitat Rovira $i$ Virgili (URV), Tarragona (Spain). \\ 2 Department of Education Sciences and Psychology. Universitat Oberta de Catalunya (UOC), Barcelona (Spain)
}

\begin{abstract}
Título: Variables predictivas de la calidad del sueño en conductores profesionales

Resumen: Los conductores profesionales suelen padecer problemas para dormir o descansar correctamente. Esto puede deberse a diversos factores tanto personales como específicos de las condiciones laborales. En el presente trabajo nos hemos planteado desarrollar un modelo predictivo sobre la calidad del sueño en conductores profesionales utilizando los indicadores siguientes: Edad, Género, Confort del asiento, suspensión del asiento, Soporte lumbar ajustable del asiento del conductor, Horas de conducción, Problemas musculoesqueléticos, Drivers Stress, Irritación, Personalidad resistente, Burnout, Conductas de seguridad e Impulsividad. Método: Los participantes han sido 369 conductores profesionales, de distintos sectores del transporte, obtenidos mediante un muestreo no probabilístico. Se ha utilizado el programa SPSS 25.0. Resultados: Se determina la capacidad predictiva de algunas variables que afectan a los conductores sobre la calidad del sueño. Conclusiones: La calidad del sueño se puede predecir a través de determinadas variables, siendo la mejor predictora Exhaustion (Burnout). Esta investigación contribuye a un mayor conocimiento de la calidad del sueño y a la mejora de la salud de los conductores profesionales. Palabras clave: Conductores profesionales. Calidad del sueño. Salud laboral. Ergonomía. Trastornos psicofisiológicos. Riesgos laborales.
\end{abstract}

\section{Introduction}

Sleeping is a neurobiological need that alternates with waking states in predetermined cycles (Gala et al., 2003). When sleep disturbances occur, somnolence deteriorates psychomotor and neurocognitive functional variables such as attention, reaction time, surveillance capacity and information processing. When this happens, drivers may experience an increase in traffic accidents. Drowsiness during driving is a leading cause of accidents and can be reduced if corrective measures are taken (Connor et al., 2002).

Filtness et al. (2014) demonstrated that drowsiness decreases the driver's ability to maneuver the vehicle and increases the probability of nodding off and falling asleep at the wheel. This leads to dangerous situations for the drivers themselves as well as for other drivers, with high mortality rates and damage to infrastructure (Lyznicki et al., 1998). Some studies have found that bus drivers experience poor sleep quality, which is of great concern for public safety and passengers alike (Chaiard et al., 2019; Diez et al., 2011; Sunwoo et al., 2017).

\section{* Correspondence address [Dirección para correspondencia]}

María-José Serrano-Fernández, Ph.D. Professor of Psychology and Education. Universitat Rovira i Virgili (URV, Tarragona, Spain).

Faculty of Education Sciences and Psychology.

Campus Sescelades. Ctra Valls, s/n, Tarragona 43007 (Spain).

E-mail: mariajose.serrano@urv.cat

(Article received: 25-03-2020, revised: 08-09-2020, accepted: 17-11-2020)
Abstract: Professional drivers often have problems sleeping or resting properly. This may be due to various factors, both personal and specific to their working conditions. In this study, we set out to develop a predictive model for the quality of sleep in professional drivers using the following indicators: Age, Gender, Seat Comfort, Seat Suspension, Adjustable Lumbar Support of the Driver's Seat, Driving Hours, Musculoskeletal Problems, Driver Stress, Irritation, Resistant Personality, Burnout, Safety Behaviors and Impulsivity. Method: The participants were 369 professional drivers from different transport sectors, obtained through nonprobabilistic sampling. The SPSS 25.0 program was used for statistical analysis. Results: The predictive capacity of certain variables that affect drivers' sleep quality is determined. Conclusions: Sleep quality can be predicted by means of certain variables, the best predictor of which is Exhaustion (Burnout). This research contributes to the body of knowledge on sleep quality and on improving the health of professional drivers.

Keywords: Sleep quality. Occupational health. Ergonomics. Professional drivers. Psychophysiological disorders. Occupational risks.
Professional drivers are a group susceptible to health risks. Taylor and Dorn (2006) claim that apart from the effects on health, stress and fatigue in bus drivers can increase the risk of accidents. Other factors such as long working hours, compliance with schedules, and responsibility for the safety of passengers can also cause stress (Greiner et al., 1998). Work stress produces alterations in the biological markers of stress (cortisol) and in cardiovascular parameters that show a state of physiological hyperactivation (MoyaAlbiol et al., 2005). Both interfere with the ability to rest well, as shown by Akerstedt et al. (2002), who found a significant negative correlation between work stress and sleep quality. Other authors (Gosselin et al., 2005; Miró \& BuelaCasal, 2005) have indicated that a lack of sleep or altered sleep generates fatigue, alters mood, worsens performance, gives rise to changes in numerous physiological systems, and affects immunosuppression.

Factors related to work, such as shift work or long working hours, play a substantial role in the loss of sleep. Thus, professional drivers, whose work demands a lot of time, are at higher risk of accidents, and more serious ones, than nonprofessional drivers (Braeckman et al., 2011; De Pinho et al., 2006; Philip, 2006). Therefore, work such as theirs, which requires sustained surveillance and rapid reaction times, is severely compromised by drowsiness (Braeckman et al., 2011).

Among transport professionals, sleep dysfunctions have been associated with work stress and working hours (Åkerstedt et al., 2002), fatigue (Åkerstedt et al., 2004), and 
performance (Bonnet, 1985). The presence of physiological or cognitive arousal when going to sleep is a sign of sleep disturbance ( $\AA$ kerstedt et al., 2002). Occupational concerns also affect the quality of sleep (Kecklund \& Åkerstedt, 2004), as do the working conditions of professional drivers. Santos and $\mathrm{Lu}$ (2016) indicate that bus drivers work an average of 16 hours a day. They perform risky tasks such as fast passenger loading and rushing to stay on schedule, which have been found to affect the mental health of these drivers (da Silva-Júnior et al., 2009; Hilton et al., 2009; van der Ploeg \& Kleber, 2003). Gómez-Ortiz, Cendales, Useche and Bocarejo (2018) found that drivers' mental health problems were associated with work pressure, little support from co-workers, few rewards and high signal conflict while driving. In addition, the static posture and limited freedom of movement to which they are subjected aggravate the muscular tension accumulated during work (Evans, 1994; Tse et al., 2006).

Professional drivers can experience high physical loads due to the high density of traffic and the constant stops they must make (Rayo et al., 2007), in addition to the simultaneous performance of numerous and frequent tasks while exposed to vibrations and noise (Göbel et al., 1998; Rayo et al., 2007). Fatigue at work is related to the number of hours worked (Fletcher \& Dawson, 2001). Thus, fatigue and the need for recovery are mediating variables in the association between work stress and risky driving, and between social support and risky driving (Useche et al., 2017). In addition, fatigue has been found to be a major contributing factor to truck accidents (Castro et al., 2004; Chen \& Xie, 2014; Muñoz-Escobar, 2018).

Driving has also been related to burnout (Arias et al., 2013; Couto \& Lawoko, 2011; Olivares et al., 2013; Sanchez, 2016). McVicar (2003) suggests that the absence of sleep may be a precursor to burnout. In fact, it has been shown that the most powerful predictor of mental fatigue (burnout) is the alteration of sleep ( $\AA$ kerstedt et al., 2004). In this research, we have taken into consideration the importance of personal factors in the resilience and vulnerability of professional drivers. Hardiness is closely related to workers' health, as it reveals that people with resilient personalities perceive fewer stressful situations as stressful, and therefore approach them more actively (Kobasa, 1979, 1982). This has led us to formulate the following hypothesis:

Hypothesis: If sleep quality is influenced by Age, Gender, Seat Comfort, Seat Suspension, Adjustable Lumbar Support of the Driver's Seat, Hours Driven, Musculoskeletal Disorders, Driver Stress, Irritation, Resistant Personality, Burnout, Safety Behaviors and Impulsivity, then a standard for relaxed driving can be derived from a model that incorporates these predictors.

Basantes et al. (2017) found that the most common risks faced by professional drivers include traffic accidents; long hours of driving without rest; physical agents (dazzle, vibrations and exposure to adverse weather); and the physical, visual, and mental load caused by factors such as the number of hours worked, nocturnality, isolation, monotony and stress. In addition, Sunwoo et al. (2017) found that the most prevalent risk factor for sleepy driving was depression.

In Spain, the General Directorate of Traffic (DGT, 2006) carried out an advertising campaign to prevent accidents due to sleep, in which it indicated that drivers were at great risk because they suffer from chronic drowsiness. This campaign aimed to help drivers detect drowsiness by explaining that the main symptoms of sleep are difficulty maintaining a safe distance, moving a lot in the seat and problems with maintaining attention and it recommended that drivers go to the doctor.

According to the press release published by the Ministry of the Interior (DGT, 2018), the most important factors involved in traffic accidents were alcohol and / or illegal drugs ( $42 \%$ of cases), distraction $(36 \%)$, tiredness or falling asleep $(22 \%)$ and inadequate speed $(19 \%)$, the latter three being due to lack of sleep, so in view of the data shown it is necessary to have indicators that can help prevent drowsiness. According to the General Directorate of Traffic (DGT, 2018), in Spain sleep and fatigue were the main cause in 2017 of 2,722 traffic accidents with specifically 177 deaths and 4,063 injured victims, of which 589 required hospitalization.

Sleep is a basic need, the study Awake Europe (DGT, 2013) showed that driving while sleepy had affected $70 \%$ of the participants, indicating that if they also suffer from sleep apnea they are up to 2 or 3 times more likely to have an accident .

An important piece of information is that shown by Williamson and Feyer (2000), which indicates that being awake for 19 hours causes cognitive impairment compatible with having a blood alcohol content of .05\% and if it goes beyond 24 hours it is comparable to a $.10 \%$. At the moment the limit in our country blood alcohol limits are: drivers in general $.05 \mathrm{gr} / \mathrm{l}$, professional drivers $.3 \mathrm{gr} / 1$ and novice drivers 3 gr / 1 (Real Decreto 1428/2003, 2003).

Therefore, it is important to identify those factors that may affect the quality of sleep, since the possible results that emerge from this research would help to understand the factors involved, allowing individual interventions to improve those relevant aspects in each person.

\section{Method}

\section{Participants}

The study participants were 369 Spanish professional drivers (93.3\% male, $6.7 \%$ female). The mean age was 41.3 $(S D=11.01)$. The drivers work in public passenger transportation $(33.1 \%)$, taxi driving $(35.1 \%)$, freight transport $(27.2 \%)$ and ambulance driving $(4.6 \%)$. The average years of experience was $9.6(S D=11.05)$, and the average length of time working as a professional driver was 11.16 (SD = 12.15). The civil status distribution was married or cohabiting $(71.7 \%)$, single $(20.8 \%)$, divorced/separated/widowed $(7.5 \%)$. 
The education level of the subjects was as follows: professional training-I or upper secondary school (54.4\%); professional training-II, lower secondary school or prep school $(22.3 \%)$; primary education certificate or less $(21.1 \%)$ and university studies $(2.2 \%)$.

\section{Instruments}

The Groningen Sleep Scale (SSQ-8; Serrano-Fernández, Boada-Grau, Robert-Sentís, et al., n.d.) is the Spanish adaptation of the GSQS-15 (Meijman et al., 1988) and evaluates the subjective quality of sleep such as the general quality of sleep, lack of sleep, difficulty in falling asleep, problems sleeping and not resting. Its structure is unifactorial $(\alpha=.90)$ and responses are recorded on a six-point scale (1. Strongly disagree to 6. Strongly agree). An example of an item would be, "1. Last night I slept soundly."

The Musculoskeletal Problems Scale (MP-9; Robb \& Mansfield, 2007), in the version adapted to Spanish by Robert-Sentís (2016), evaluates musculoskeletal problems and vibrations and consists of nine items. Its structure is bifactorial: "F1. Musculoskeletal aspects" (referring to the trunk, e.g., shoulders) ( $\alpha=.72$ ); and "F2. Extremities" (e.g., knees). The vibrations considered are those that affect the comfort of the seat and the lumbar adjustment $(\alpha=$. 70). It is answered on a five-point Likert scale (1. Never to 5. Always).

In order to evaluate stress in driving we used the Trans Driver Stress Scale (TDS-15; (Serrano-Fernández et al., 2018). This refers to the driver's state of relaxation or tension before, during, and after driving. "F2. Preventing Haz$\operatorname{ards"}(\mathrm{PH} ; \alpha=.71)$ indicates the effort that is made while driving and the possible dangers that may be encountered while driving on the road. "F3. Alertness and Surveillance" (AS; $\alpha=.70$ ) refers to the ease with which the driver can relax while or after driving. "F4. Thrill Seeking" (TS; $\alpha=.76$ ) refers to the manner in which the driver drives (risky vs. prudent). "F5 Fatigue and Anxiety" (FA; $\alpha=.70)$ indicates the fatigue and nervousness of the professional driver. These items are rated on a six-point Likert scale (from 1. Strongly disagree to 6. Strongly agree).

The Dickman's Impulsivity Inventory Scale (Dickman, 1990), in its Spanish version (Chico, Tous, Lorenzo-Seva, \& Vigil-Colet, 2003), is made up of 23 items and 2 subscales "F1. Functional impulsiveness" assesses impulsiveness that is beneficial and that can help one to adapt to unexpected situations which require a quick response (11 items; $\alpha=.77$; e.g., "9. I like to take part in quick conversations where there really isn't much time to think before I speak"). "F2. Dysfunctional impulsiveness" refers to impulsiveness that, as opposed to being advantageous, can be counterproductive (12 items; $\alpha=.76$; e.g., "11. I often don't spend a lot of time thinking about a situation before acting"). The response format is dichotomous $(1=$ true $/ 0=$ false $)$.

The TRANS-18 Scale evaluate psychophysiological disorders and safety behaviors, both personal and in the vehicle
(Boada-Grau et al., 2012). It is made up of 18 items and three dimensions. "F1. Psychophysiological Disorders", its refers to disorders that the driver may suffer, such as stress, anxiety, depression, musculoskeletal disorders, digestive disorders and hypertension. ( $\alpha=.81$; e.g., "14. My work has produced some muscular and / or skeletal disorder (for example, low back pain, tendinitis, etc.”). "F2. Personal Safety Behaviors", its refers to not driving after drinking alcohol or having a large meal. Also to the fact of not eating or drinking while driving ( $\alpha=.80$; e.g., "4. I avoid driving while drinking a soda"). "F3. Vehicle Safety Behaviors", has to do with putting on work gloves to perform job tasks, knowing how to use extinguishers, being alert while driving and resting the mandatory hours ( $\alpha=.70$; e.g., " 9 . I use caution when getting out of my vehicle"). The responses are recorded on a five-point Likert scale and range from 1. Never to 5. Always.

The Hardy Personality scale (CPR; Moreno-Jiménez, González, \& Garrosa, 2001) is made up of 21 items and three dimensions with seven items each one. "F1. Control" is about the subjects' own sense of their influence on events $(\alpha=.74$; e.g., " 3 . I do everything I can to ensure control of the results of my work."). "F2. Commitment" is defined as the tendency to develop behaviors that entail personal involvement, the tendency to identify with what one does $(\alpha=$ .79; e.g., "10. My daily work satisfies me and makes me totally dedicate myself to it"). "F3. Challenge" indicates that potentially stressful stimuli are perceived as opportunities for growth ( $\alpha=.83$; e.g., " 8 . In my professional work I am attracted to those tasks and situations that imply a personal challenge"). The responses are recorded on a four-point Likert scale (from 1. Totally disagree to 4. Totally agree).

The Burnout scale (MBI-GS; Salanova, Schaufeli, Llorens, Peiró, \& Grau, 2000) evaluates burnout and comprises 15 items ( 3 subscales). The subscale of "Exhaustion $(\alpha=.87)$ " is made up of five items (e.g., " 6 . I feel 'burned out' by work"). "Cynicism ( $\alpha=.85)$ " consists of five items (e.g., "9. I have lost enthusiasm for my work") and "Professional Efficiency $(\alpha=.78)$ " comprises six items (e.g., "12. I have achieved a lot of worthwhile things in this position"). Responses are given on a seven-point Likert-type scale ranging from 0. Never / At no time to 6. Always / every day.

The Irritation Scale (A. Mohr, 1986; G. Mohr et al., 2006), adapted to Spanish by Merino, Carbonero, MorenoJiménez and Morante (2006), has eight items and two subscales. The first subscale is called "Factor 1. Emotional Irritation" (5 items (Cronbach's alpha =.86) e.g., "6. I get angry easily") and the second is called "Factor 2. Cognitive Irritation" (3 items (Cronbach's alpha =.87) e.g., "4. Even on vacation sometimes I cannot stop thinking about work problems"). It makes use of a six-point Likert scale (from 1. Strongly disagree to 6. Strongly agree).

We also collected other data on age, seat comfort, seat suspension, driver's seat adjustable lumbar support, and weekly hours of driving. 


\section{Procedure}

The sample was obtained by non-probability sampling (Hernández et al., 2004), also known as accidental-random sampling (Kerlinger \& Lee, 2004). To collect the data, the directors of several transport companies were initially contacted by telephone and asked the most opportune time to access the drivers. They were also given a booklet, which they had to answer in their usual working place, which included a cover letter, informed consent and questionnaires to answer. The participants were informed that the data obtained is completely confidential and anonymous. The response rate was approximately $80 \%$ and corresponds to those drivers who voluntarily and without receiving any kind of payment agreed to participate in the study

\section{Data Analysis}

First, the Kolmogorov-Smirnov test was used to check the normality of the data, showing this to be a good fit. The next step in the analysis consisted of calculating the correlations between the predictor variables and the criterion variables using Pearson's correlation coefficients. We then performed multiple regressions using IBM SPSS Statistics 25 software with the stepwise option (Hinton et al., 2014). This method incorporates the variables into the regression model. There were twenty-six variables corresponding to Age, Gender, Seat Comfort, Seat Suspension, Adjustable Lumbar Support, Hours Driven per Week, Musculoskeletal Problems, Driver Stress, Irritation, Resistant Personality, Burnout, Safety and Impulsivity Behaviors. This method begins by selecting the independent variable that, in addition to exceeding the input criteria, has a higher correlation (in absolute value) with the dependent variable. It then selects the independent variable that, in addition to passing the input criteria, has the highest partial correlation coefficient (in absolute value). With this procedure, each time a new variable is incorporated in the model, the previously selected variables are evaluated again in order to check if they meet the exit criteria. The variable of the model is excluded when it meets the exit criteria. The process ends when there were no more predictive variables that met the entry criteria and no selected variable that met the exit criteria. Through this procedure, we can explain the maximum variance with the minimum possible number of predictive variables.

\section{Results}

\section{Reliability analysis}

Table 1 shows the instruments used in the present investigation. The indices for internal consistency are appropriate given that they range between .87 (Exhaustion) and .70 (Relaxed Driving).
Table 1

Descriptive statistics and reliability values with Cronbach's alpha coefficient. \begin{tabular}{lcccrr}
\hline Variable & Minimum & Maximum & Mean & $S D$ & $\alpha$ \\
\hline GSQS8 & 4 & 36 & 6.23 & 8.85 & .80
\end{tabular}

$\begin{array}{llllll}\text { ME.Trunk } & 4 & 20 & 9.84 & 3.22 & .72\end{array}$

$\begin{array}{llllll}\text { ME.Extrem } & 5 & 20 & 8.18 & 2.99 & .71\end{array}$

$\begin{array}{llllll}\text { TDS15.RD } & 3 & 12 & 4.98 & 3.39 & .70\end{array}$

$\begin{array}{llllll}\text { TDS15.PH } & 3 & 18 & 15.92 & 2.51 & .71\end{array}$

$\begin{array}{llllll}\text { TDS15.AS } & 3 & 18 & 14.54 & 3.13 & .72\end{array}$

$\begin{array}{llllll}\text { TDS15.TS } & 3 & 18 & 6.90 & 3.32 & .75\end{array}$

$\begin{array}{llllll}\text { TDS15.FA } & 3 & 18 & 7.36 & 3.46 & .71\end{array}$

$\begin{array}{llllll}\text { IE } & 5 & 35 & 11.05 & 5.33 & .82\end{array}$

$\begin{array}{llllll}\text { IC } & 3 & 21 & 7.15 & 4.17 & .83\end{array}$

$\begin{array}{llllll}\text { CPR.I } & 10 & 28 & 22.14 & 3.63 & .82\end{array}$

$\begin{array}{llllll}\text { CPR.R } & 7 & 28 & 20.69 & 3.90 & .86\end{array}$

$\begin{array}{llllll}\text { CPR.C } & 7 & 28 & 22.08 & 3.00 & .71\end{array}$

$\begin{array}{llllll}\text { MBI.E } & 0 & 28 & 9.40 & 6.08 & .87\end{array}$

$\begin{array}{llllll}\text { MBI.C } & 0 & 21 & 6.21 & 5.19 & .80\end{array}$

$\begin{array}{llllll}\text { MBI.EP } & 10 & 36 & 28.86 & 5.14 & .71\end{array}$

$\begin{array}{llllll}\text { T18.TP } & 6 & 30 & 11.32 & 3.71 & .74\end{array}$

$\begin{array}{llllll}\text { T18.SP } & 6 & 30 & 22.36 & 4.90 & .75\end{array}$

$\begin{array}{llllll}\text { T18.SV } & 14 & 30 & 24.85 & 3.80 & .74\end{array}$

$\begin{array}{llllll}\text { IMP.F } & 0 & 11 & 5.65 & 2.44 & .75\end{array}$

\begin{tabular}{llllll} 
IMP.D & 0 & 11 & 3.12 & 2.50 & .74 \\
\hline
\end{tabular}

Variables used in the research: Sleep quality (GSQS8), Relaxed driving (TDS15.RD), Preventing Hazards (TDS15.PH), Alert and Surveillance (TDS15.AS), Thrill Seeking (TDS15.TS), Fatigue and Anxiety (TDS15.FA), Emotional Irritation (IE), Cognitive Irritation (IC), Implication (CPR.I), Challenge (CPR.R),Control (CPR.C), Exhaustion (MBI.E), Cynicism (MBI.C), Professional efficiency (MBI.EP), Psychophysiological Disorders (T18.TP), Personal safety behaviors (T18.SP), Vehicle safety behaviors (T18.SV), Functional impulsivity (IMP.F), Dysfunctional impulsivity (IMP.D), Age, Gender, Seat comfort, Seat suspension, Adjustable lumbar support, Hours driven a week.

\section{Correlation analyses}

The correlational study shown below (Table 2) only displays the correlations between the criterion variables and the predictor variables in this study. We extracted the following correlations from the study and found a positive correlation between Sleep Quality (GSQS8) and nine variables: ME Trunk, ME Extrem, Thrill Seeking (TDS15.TS), Fatigue and Anxiety (TDS15.FA), Emotional and Cognitive Irritation (IE/IC), Exhaustion (MBI.E), Cynicism (MBI.C), Psychophysiological Disorders (T18.TP). We found negative correlations between Sleep Quality (GSQS8) and eight variables: Seat Comfort, Seat Suspension, Adjustable Lumbar Support, Relaxed Driving (TDS15.RD), Implication (CPR.IMP), Challenge (CPR.R), Control (CPR.C) and Functional Impulsivity (IMP.F). 
Table 2

Correlations between the predictor variables and the criterion variables.

\begin{tabular}{lc}
\hline & Criterion variable \\
Predictor variables & GSQS8 \\
& SLEEP \\
\hline Age & .002 \\
Gender & .001 \\
Seat comfort & $-.161^{*}$ \\
Seat suspension & $-.186^{* *}$ \\
\hline Adjustable lumbar support & $-.203^{* *}$ \\
Hours driven a week & .016 \\
ME.Trunk & $.239^{* *}$ \\
ME.Extrem & $.257^{* *}$ \\
TDS15.RD & $-.248^{* *}$ \\
TDS15.PH & -.083 \\
TDS15.AS & .004 \\
TDS15.TS & $.147^{* *}$ \\
TDS15.FA & $.308^{* *}$ \\
IE & $.368^{* *}$ \\
IC & $.361^{* *}$ \\
CPR.I & $-.246^{* *}$ \\
CPR.R & $-.174^{* *}$ \\
CPR.C & $-.139^{*}$ \\
MBI.E & $.444^{* *}$ \\
MBI.C & $.267^{* *}$ \\
MBI.EP & -.052 \\
T18.TP & $.256^{* *}$ \\
T18.SP & -.118 \\
IMP.F & -.101 \\
IMP.D & $-.231^{* *}$ \\
** The correlation is significant at the level .01 (bilateral). & -.051 \\
The correlation is significant at the level .05 (bilateral). \\
\end{tabular}

** The correlation is significant at the level .01 (bilateral).
$*$ The correlation is significant at the level .05 (bilateral).

\section{Multiple regression}

A multiple regression model was performed to test the effects of predictor variables (twenty-six) on criterion variables in connection with the Sleep Quality. This statistical technique provides an objective way to evaluate the predictive ability of a set of independent variables (Hair et al., 1999). To reduce the type 1 error rate, the Bonferroni correction is applied, considering in our case .002 as a significant level. The data corresponding to the adjusted $R^{2}$ indices and significant typified beta coefficients between the criterion variables and predictive variables in this study are shown in Table 3. Two multiple linear regression models were used for this purpose.

The model aimed to identify the degree to which these predictor variables were capable of predicting Sleep Quality (Figure 1). Table 3 presents a summary of the model and shows that the predictor variables were Exhaustion (MBI.E), Functional Impulsivity (IMP.F), Implication (CPR.I), Alertness and Surveillance (TDS15.AS) and Fatigue and Anxiety (TDS15.FA) and account for $36.1 \%$ of the criterion variable's variance. They have analyzed the diagrams for all the regressions and they have not observed problems of homocedasticity or excess residuals. The Exhaustion variable stands out as the best predictor, accounting for $21.9 \%$ of variance. The beta coefficient values are among the most telling aspects, and illustrate that the predictor variables which were found to be statistically significant were Exhaustion $(\beta=.480 ; p=.000)$, Functional Impulsivity $(\beta=-.766$; $p=.001)$ and Emotional Irritation $(\beta=.307 ; p=.019)$. The linear regression assumption that the residual variances have a Gaussian distribution was verified using a post-hoc power analysis based on the observed effect size. According to a multiple regression post hoc power calculation, we found that in all powers the power is above $80 \%$ with a type I error rate of .05 .

Table 3

Summary of the models, variables and coefficients of regression analysis (stepwise method) for the Sleep.

\begin{tabular}{|c|c|c|c|c|c|c|c|c|c|c|c|}
\hline \multirow{2}{*}{$\begin{array}{l}\text { Models and } \\
\text { Variables }\end{array}$} & \multicolumn{6}{|c|}{ Models } & \multicolumn{5}{|c|}{ Coefficients } \\
\hline & $R$ & $R^{2}$ & $\mathrm{R}^{2}$ Adjusted & $R_{\text {Change }}$ & $F_{\text {Change }}$ & $\operatorname{sig}$ & B & $\mathrm{SE}$ & $\beta$ & $t$ & sig \\
\hline Model-1 & .472 & .223 & .219 & .223 & 52.012 & .000 & & & & & \\
\hline MBI.E & & & & & & & .674 & .094 & .472 & 7.212 & .000 \\
\hline Model-2 & .522 & .272 & .264 & .049 & 12.170 & .001 & & & & & \\
\hline MBI.E & & & & & & & .658 & .091 & .461 & 7.244 & .000 \\
\hline IMP.F & & & & & & & -.802 & .230 & -.222 & -3.489 & .001 \\
\hline Model-3 & .543 & .294 & .283 & .022 & 5.580 & .019 & & & & & \\
\hline MBI.E & & & & & & & .480 & .117 & .337 & 4.102 & .000 \\
\hline IMP.F & & & & & & & -.766 & .227 & -.212 & -3.372 & .001 \\
\hline $\operatorname{IrrE}$ & & & & & & & .307 & .130 & .194 & 2.362 & .019 \\
\hline
\end{tabular}

Excluded variables: Age, Gender, Seat comfort, Seat suspension, Adjustable lumbar support, ME.Trunk, ME.Extr, TDS15.RD, TDS15.PH, TDS15.AS, TDS15.TS, TDS15.FA, IrrC, CPR.I, CPR.R, CPR.C, MBI.C, MBI.EP, T18.TP, T18.SP, T18.SV, IMP.F and IMP.D. 
Figure 1

Model followed in this research.

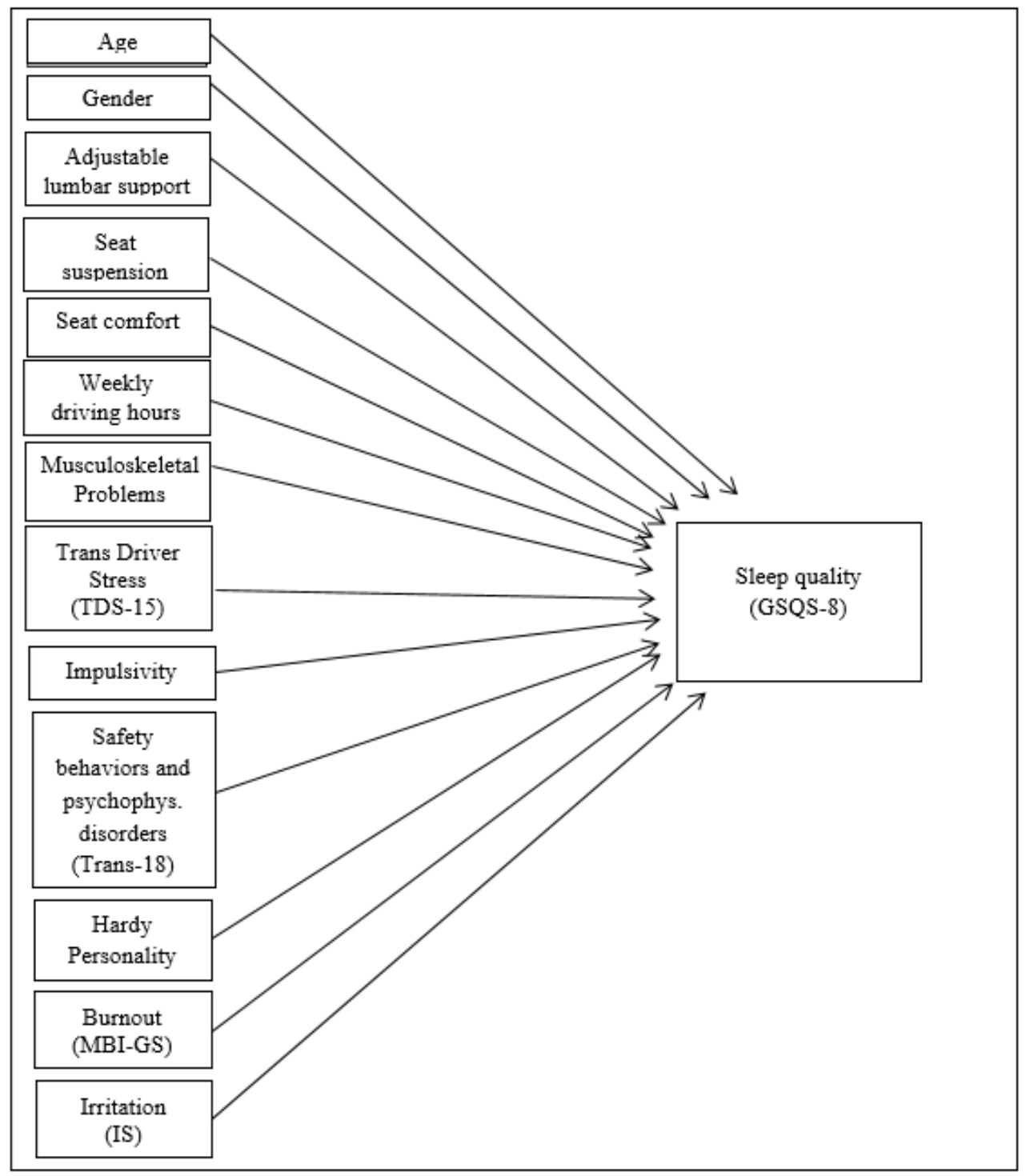

\section{Discussion}

The results presented above are consistent with the notion that certain variables have predictive power over factors related to Sleep Quality in professional drivers.

The hypothesis is partially supported since it can be seen that the best predictive model for Sleep Quality problems is that which includes three variables as positive predictors: Exhaustion, Functional Impulsivity and Emotional Irritation. This could be because these factors cause stress in drivers (Boada-Grau et al., 2013). This is manifested by work stress altering the biological markers of stress (cortisol) and physiological hyperactivation (Moya-Albiol et al., 2005) both incompatible with good rest, as documented in Åkerstedt et al. (2002). These authors found a negative and significant cor- relation between work tension and sleep quality. Other authors (Gosselin et al., 2005; Miró \& Buela-Casal, 2005) indicate that a lack of sleep (or altered sleep) generates fatigue, disturbs mood, worsens performance and produces changes in numerous bodily systems and immunosuppression, and this can become a cycle. We must bear in mind that Exhaustion is shown as the best predictor, which is caused by the stress that is generated in drivers when driving in conditions in which they perceive they might fall asleep at the wheel (Filtness et al., 2014; Sabbagh-Ehrlich et al., 2005).

On the other hand, we found that Functional Impulsivity act as negative predictor. Some researchers have shown that involvement in work reduces the impact of work demands and stress (Bakker et al., 2005; Balducci et al., 2011; Van de Ven et al., 2013). While functional impulsivity is favorable 
and helps one to adapt to unexpected situations that require rapid response (Dickman, 1990). Thus, functional impulsivity and involvement in work, being negative predictors, facilitate the quality of sleep by not favoring the presence of stress.

In conclusion, the results highlight the importance of designing individual interventions to reduce the incidence of drowsiness in professional drivers, which would provide greater comfort to the driver and the consequent reduction of accident risks. It has been observed that the variables Exhaustion, Functional Impulsivity and Emotional Irritation are positive predictors, so individual interventions should be aimed at reducing the levels of exhaustion and emotional irritation that may be the result of the nature of the work; the interventions found in the literature are aimed at getting drivers to stop, have a drink, move about and even sleep a little, which for some is not possible due to the nature of their work (for example, having to meet certain schedules) for that reason each case must be analyzed and individually corrections must be applied.

This study is not without limitations. In the first place, in the population studied here, the number of women who drive professionally is very small, so it would be advisable to conduct a study in a sample with a greater representation of females. In addition, the data was obtained through selfreports. The use of self-reporting can produce biases that can range from social desirability to lack of sincerity (Razavi, 2001).

\section{References}

Åkerstedt, T., Knutsson, A., Westerholm, P., Theorell, T., Alfredsson, L., \& Kecklund, G. (2002). Sleep disturbances, work stress and work hours. Journal of Psychosomatic Research, 53(3), 741-748. https://doi.org/10.1016/S0022-3999(02)00333-1

Åkerstedt, T., Knutsson, A., Westerholm, P., Theorell, T., Alfredsson, L., \& Kecklund, G. (2004). Mental fatigue, work and sleep. Journal of Psychosomatic Research, 57(5), 427-433. https://doi.org/10.1016/j.jpsychores.2003.12.001

Arias, W. L., Mendoza, L., \& Masias, M. A. (2013). Síndrome de Burnout en conductores de transporte público de la ciudad de Arequipa [Burnout syndrome in public transport drivers in the city of Arequipa]. Revista de Peruana de Psicología y Trabajo Social, 2(2), 111-122.

Bakker, A. B., Demerouti, E., \& Euwema, M. C. (2005). Job resources buffer the impact of job demands on burnout. Journal of Occupational Health Psychology, 10(2), 170-180. https://doi.org/10.1037/10768998.10.2.170

Balducci, C., Schaufeli, W. B., \& Fraccaroli, F. (2011). The job demandsresources model and counterproductive work behaviour: The role of job-related affect. European Journal of Work and Organizational Psychology, 20(4), 467-496. https://doi.org/10.1080/13594321003669061

Basantes, V., Parra, C., Garcia, J., Jo de Carvallo, J., \& Garcia, Y. (2017). Evaluación de los riesgos ocupacionales asociados a indicadores bioquímicos en conductores profesionales [Assessment of occupational risks associated with biochemical indicators in professional drivers]. Revista Médica Electrónica, 39, 33-42.

Boada-Grau, J., Prizmic-Kuzmica, A.-J., González-Recio, S., \& Vigil-Colet, A. (2013). Estresores laborales en conductores de autobuses (ELBus21): Estructura factorial, fiabilidad y validez [Occupational stressors in bus drivers (ELBus-21): factorial structure, reliability and validity]. Universitas Psychologica, 12(1), 249-259. https://doi.org/10.11144/JAVERIANA.UPSY12-1.ELCA

Boada-Grau, J., Sánchez-García, J. C., Prizmic-Kuzmica, A. J., \& VigilColet, A. (2012). Health and Safety at Work in the Transport Industry (TRANS-18): Factorial Structure, Reliability and Validity. The Spanish Journal of Psychology, 15(1), 357-366. https://doi.org/10.5209/rev SJOP.2012.v15.n1.37342

Bonnet, M. H. (1985). Effect of sleep disruption on sleep, performance, and mood. Sleep, 8(1), 11-19. https://doi.org/10.1093/sleep/8.1.11

Braeckman, L., Verpraet, R., Van Risseghem, M., Pevernagie, D., \& De Bacquer, D. (2011). Prevalence and Correlates of Poor Sleep Quality and Daytime Sleepiness in Belgian Truck Drivers. Chronobiology International, $28(2)$

126-134. https://doi.org/10.3109/07420528.2010.540363

Castro, J. R. de, Gallo, J., \& Loureiro, H. (2004). Cansancio y somnolencia en conductores de ómnibus y accidentes de carretera en el Perú: estudio cuantitativo [Tiredness and sleepiness in bus drivers and road accidents in Peru: quantitative study]. Revista Panamericana de Salud Pública, 16, 1118. https://doi.org/10.1590/S1020-49892004000700002

Chaiard, J., Deeluea, J., Suksatit, B., \& Songkham, W. (2019). Factors Associated with Sleep Quality of Thai Intercity Bus Drivers. Industrial Health, 2018-0168. https://doi.org/10.2486/indhealth.2018-0168

Chen, C., \& Xie, Y. (2014). Modeling the safety impacts of driving hours and rest breaks on truck drivers considering time-dependent covariates. Journal of Safety Research, 51, 57-63. https://doi.org/10.1016/i.jsr.2014.09.006

Connor, J., Norton, R., Ameratunga, S., Robinson, E., Civil, I., Dunn, R., Baley, J., \& Jackson, R. (2002). Driver sleepiness and risk of serious injury to car occupants: population based case control study. British Medical Journal, 324, 1125-1125. https://doi.org/10.1136/bmi.324.7346.1125

Couto, M. T., \& Lawoko, S. (2011). Burnout, workplace violence and social support among drivers and conductors in the road passenger transport sector in Maputo city, Mozambique. Journal of Occupational Health, 53, 214-221. https://doi.org/10.1539/joh.L10102

da Silva-Júnior, F. P., Nunes de Pinho, R. S., de Mello, M. T., Sales de Bruin, V. M., \& Carvalhedo de Buin, P. F. (2009). Risk factors for depression in truck drivers. Social Psychiatry and Psychiatric Epidemiology, 44(2), 125-129. https://doi.org/10.1007/s00127-008-0412-3

De Pinho, R. S. N., da Silva-Júnior, F. P., Bastos, J. P. C., Maia, W. S., De Mello, M. T., De Bruin, V. M. S., \& De Bruin, P. F. C. (2006). Hypersomnolence and accidents in truck drivers: A cross-sectional study. Chronobiology International, 23(5), 963-971. https://doi.org/10.1080/07420520600920759

Dickman, S. J. (1990). Functional and dysfunctional impulsivity: Personality and cognitive correlates. Journal of Personality and Social Psychology, 58(1), 95-102. https://doi.org/10.1037/0022-3514.58.1.95

Diez, J. J., Vigo, D. E., Lloret, S. P., Rigters, S., Role, N., Cardinali, D. P., \& Chada, D. P. (2011). Sleep habits, alertness, cortisol levels, and cardiac autonomic activity in short-distance bus drivers: Differences between morning and afternoon shifts. Journal of Occupational and Environmental Medicine, $53(7)$ 806-811. https://doi.org/10.1097/JOM.0b013e318221c6de

Dirección General de Tráfico (DGT). (2006). El sueño es una de las principales causas de accidente en carretera [Sleep is one of the main causes of road accidents]. Ministerio del Interior. http://www.dgt.es/es/ladgt/campanas/2006/El-suenio-es-una-de-las-principales-causas-deaccidente-en-carretera.shtml

Dirección General de Tráfico (DGT). (2013). El 70\% de los conductores se duerme $[70 \%$ of drivers fell asleep]. Ministerio del Interior. http://revista.dgt.es/es/noticias/nacional/2013/el-70-por-100-de-losconductores-se-duerme.shtml\#.X4IVadAzaUk

Dirección General de Tráfico (DGT). (2018). Las salidas de vía y colisiones frontales causan 652 muertes en carreteras convencionales Road departures and head-on collisions cause 652 deaths on conventional roads 7 . Ministerio del Interior. http://www.dgt.es/es/prensa/notas-deprensa/2018/20180816_NP-Siniestralidad-convencionales.shtml 
Evans, G. W. (1994). Working on the hot seat: Urban bus operators. Accident Analysis and Prevention, 26(2), 181-193. https://doi.org/10.1016/0001-4575(94)90088-4

Filtness, A. J., Anund, A., Fors, C., Ahlström, C., Åkerstedt, T., \& Kecklund, G. (2014). Sleep-related eye symptoms and their potential for identifying driver sleepiness. Journal of Sleep Research, 23(5), 568-575. https://doi.org/10.1111/jsr.12163

Fletcher, A., \& Dawson, D. (2001). Field-based validations of a work-related fatigue model based on hours of work. Transportation Research Part F: Traffic Psychology and Behaviour, 4(1), 75-88. https://doi.org/10.1016/S1369-8478(01)00015-8

Gala, F. J., Lupiani, M., Guillén, C., Gómez, A., Lupiani, N., \& Roa, J. M. (2003). El sueño normal: perspectivas actuales [The normal dream: current perspectives]. Cuadernos de Medicina Psicosomática y Psiquiatria de Enlace, 67(68), 7-19.

Göbel, M., Springer, J., \& Scherff, J. (1998). Stress and strain of short haul bus drivers: Psychophysiology as a design oriented method for analysis. Ergonomics, 41(5), 563-580. https://doi.org/10.1080/001401398186757

Gómez-Ortiz, V., Cendales, B., Useche, S. A., \& Bocarejo, J. P. (2018). Relationships of working conditions, health problems and vehicle accidents in bus rapid transit (BRT) drivers. American Journal of Industrial Medicine, 61(4), 336-343. https://doi.org/10.1002/ajim.22821

Gosselin, A., De Koninck, J., \& Campbell, K. B. (2005). Total sleep deprivation and novelty processing: Implications for frontal lobe functioning. Clinical Neurophysiology, 116(1), 211-222. https://doi.org/10.1016/i.clinph.2004.07.033

Greiner, B. A., Krause, N., Ragland, D. R., \& Fisher, J. M. (1998). Objective stress factors, accidents, and absenteeism in transit operators: a theoretical framework and empirical evidence. Journal of Occupational Health Psychology, 3(2), 130-146. https://doi.org/10.1037/1076$\underline{8998.3 .2 .130}$

Hair, J., Anderson, R., Tatham, R., \& Black, W. (1999). Analysis Multivariante (5th ed.). Pearson Education.

Hernández, R., Fernández, C., \& Baptista, P. (2004). Metodología de la Investigación [nvestigation methodology]. McGraw-Hill Interamericana.

Hilton, M. F., Staddon, Z., Sheridan, J., \& Whiteford, H. A. (2009). The impact of mental health symptoms on heavy goods vehicle drivers' performance. Accident Analysis and Prevention, 41(3), 453-461. https://doi.org/10.1016/j.aap.2009.01.012

Hinton, P. R., McMurray, I., \& Brownlow, C. (2014). Statistics explained. McGraw-Hill.

Kecklund, G., \& Åkerstedt, T. (2004). Apprehension of the subsequent working day is associated with a low amount of slow wave sleep. Biological Psychology, $\quad$ 66(2), 169-176. https://doi.org/10.1016/i.biopsycho.2003.10.004

Kerlinger, F. N., \& Lee, H. B. (2004). Behavior Research. Research methods in social sciences. McGraw-Hill.

Kobasa, S. C. (1979). Personality and resistance to illness. American Journal of Community Psychology, 7(4), 413-423. https://doi.org/10.1007/BF00894383

Kobasa, S. C. (1982). The hardy personality: Toward a social psychology of stress and health. In G. S. Sanders \& J. Sals (Eds.), Social psychology of bealth and illness (pp. 3-32). Laurence Erlbaum Associates, Inc.

Lyznicki, J. M., Doege, T. C., Davis, R. M., \& Williams, M. A. (1998). Sleepiness, driving, and motor vehicle crashes. Journal of the American Medical Association, 279(23), 1908-1913. https://doi.org/10.1001/jama.279.23.1908

McVicar, A. (2003). Workplace stress in nursing: A literature review. Journal of Advanced Nursing, 44(6), 633-642. https://doi.org/10.1046/i.03092402.2003.02853.x

Meijman, T., de Vries-Griever, A., De Vries, G., \& Kampman, R. (1988). The evaluation of the Groningen Sleep Quality Scale. Groningen: Heymans Bulletin, HB 88-13-EX.

Merino, E., Carbonero, M. Á., Moreno-Jiménez, B., \& Morante, M. E. (2006). La Escala de Irritación como instrumento de evaluación del estrés laboral. [Irritation: Analysis of an instrument to assess stress at work]. Psicothema, 18 http://www.ncbi.nlm.nih.gov/pubmed/17296066

Miró, E., \& Buela-Casal, G. (2005). Sueño, estrés y trabajo [Sleep, stress and work]. In J. L. Arco (Ed.), Estrés y trabajo: cómo hacerlos compatibles (pp.
87-115). Junta de Andalucía, Consejería de Justicia y Administración Pública.

Mohr, A. (1986). Die Durchsetzung der Politikwissenschaft an deutschen Hochschulen und die Entwicklung der Deutschen Vereinigung für Politische Wissenschaft. In Politikwissenschaft in der Bundesrepublik Deutschland (pp. 62-77). VS Verlag für Sozialwissenschaften. https://doi.org/10.1007/978-3-663-11075-0 4

Mohr, G., Rigotti, T., Müller, A., Tschan, F., \& Aycan, Z. (2006). The Assessment of Psychological Strain in Work Contexts. European Journal of Psychological Assessment, 22(3), 198-206. https://doi.org/10.1027/1015-5759.22.3.198

Moreno-Jiménez, B., González, J. L., \& Garrosa, E. (2001). Desgaste profesional (burnout), Personalidad y Salud percibida [Burnout, Personality and Perceived Health]. In J. Buendía \& F. Ramos (Eds.), Empleo, estrés y salud. (pp. 59-83). Pirámide. https://doi.org/10.1157/13073416

Moya-Albiol, L., Serrano, M. A., González-Bono, E., Rodríguez-Alarcón, G., \& Salvador, A. (2005). Respuesta psicofisiológica del stress en una jornada laboral [Psychophysiological stress response in a workday]. Psycothema, 17(2), 205-211. https://dialnet.unirioja.es/servlet/articulo? codigo $=1128134$

Muñoz-Escobar, F. D. (2018). Fatiga, somnolencia y accidentabilidad en conductores de buses interurbanos [Fatigue, drowsiness and accidents in intercity bus drivers]. (Thesis). Universidad de Concepción, Los Ángeles (Chile).

Olivares, V. E., Jélvez, C., Mena, L., \& Lavarello, J. (2013). Estudios sobre Burnout y Carga Mental en Conductores del Transporte Público de Chile (Transantiago) [Studies on Burnout and Mental Burden in Drivers of Public Transport in Chile (Transantiago)]. Ciencia \& Trabajo, 15(48), 173-178. https://doi.org/10.4067/S0718-24492013000300011

Philip, P. (2006). Sleepiness of Occupational Drivers. Industrial Health, 43(1), 30-33. https://doi.org/10.2486/indhealth.43.30

Rayo, V., Arias, É., Álvarez, E., \& Salas, C. (2007). Especificaciones Especificaciones Ergonómicas para el Diseño Dimensional de la Cabina de Conductor de Autobús Urbano [Specifications Ergonomic Specifications for the Dimensional Design of the Urban Bus Driver's Cabin]. 5th International Conference on Occupational Risk Prevention.

Razavi, T. (2001). Self-report measures: An overview of concerns and limitations of questionnaire use in occupational stress research [monograph].

Real Decreto 1428/2003, de 21 de noviembre, por el que se aprueba el Reglamento General de Circulación para la aplicación y desarrollo del texto articulado de la Ley sobre tráfico, circulación de vehículos a motor y seguridad vial [General Traffic Regulations for the application and development of the articulated text of the Law on traffic, motor vehicle circulation and road safety], Pub. L. No. Boletín Oficial del Estado, 306, de 23/12/2003. Retrieved October 16, 2020, from https://www.boe.es/buscar/act.php?id=BOE-A-2003-23514

Robb, M. J. M., \& Mansfield, N. J. (2007). Self-reported musculoskeletal problems amongst professional truck drivers. Ergonomics, 50(6), 814 827. https://doi.org/10.1080/00140130701220341

Robert-Sentís, L. (2016). Salud laboral en conductores profesionales del transporte por carretera [Occupational health of professional road transport drivers]. (Doctoral thesis not published). Universitat Rovira i Virgili, Tarragona (Spain).

Sabbagh-Ehrlich, S., Friedman, L., \& Richter, E. D. (2005). Working conditions and fatigue in professional truck drivers at Israeli ports. Injury Prevention, 11(2), 110-114. https://doi.org/10.1136/ip.2004.007682

Salanova, M., Schaufeli, W. B., Llorens, S., Peiró, J. M., \& Grau, R. (2000). Desde el "burnout" al "Engagement" ¿una nueva perspectiva? [From "burnout" to "Engagement", a new perspective?]. Journal of Work and Organizational Psychology, 16(2), 117-134.

Sanchez, J. B. (2016). Adaptación del inventario de Burnout de Maslach en conductores de dos empresas de transporte del distrito de San Juan de Lurigancho [Adaptation of the Maslach Burnout inventory in drivers of two transport companies in the San Juan de Lurigancho district]. (unpublished thesis). Universidad César Vallejo, Lima (Perú).

Santos, J. A., \& Lu, J. L. (2016). Occupational safety conditions of bus drivers in Metro Manila, the Philippines. International Journal of Occupational Safety and Ergonomics, 22(4), 508-513. https://doi.org/10.1080/10803548.2016.1151700

Serrano-Fernández, M. J., Boada-Grau, J., Robert-Sentís, L., Boada-Cuerva, 
M., Assens-Serra, J., \& Vigil-Colet, A. (2018). Trans Driver Stress scale (TDS-15): Short scale for stress detection in professional drivers. Transportation Research Part F: Traffic Psychology and Behaviour, 58, 807-815. https://doi.org/10.1016/i.trf.2018.07.010

Serrano-Fernández, M. J., Boada-Grau, J., Robert-Sentís, L., Boada-Cuerva, M., Vigil-Colet, A., \& Assens-Serra, J. (n.d.). Spanish adaptation of the Groningen Sleep Quality Scale (GSQS-8). Universitas Psychologica.

Sunwoo, J. S., Hwangbo, Y., Kim, W. J., Chu, M. K., Yun, C. H., \& Yang, K. I. (2017). Sleep characteristics associated with drowsy driving. Sleep Medicine, 40, 4-10. https://doi.org/10.1016/i.sleep.2017.08.020

Taylor, A. H., \& Dorn, L. (2006). Stress, fatigue, health, and risk of road traffic accidents among professional drivers: The Contribution of Physical Inactivity. Annual Review of Public Health, 27(1), 371-391. https://doi.org/10.1146/annurev.publhealth.27.021405.102117

Tse, J. L. M., Flin, R., \& Mearns, K. (2006). Bus driver well-being review: 50 years of research. Transportation Research Part F: Traffic Psychology and Behaviour, 9(2), 89-114. https://doi.org/10.1016/j.trf.2005.10.002

Useche, S. A., Ortiz, V. G., \& Cendales, B. E. (2017). Stress-related psychosocial factors at work, fatigue, and risky driving behavior in bus rapid transport (BRT) drivers. Accident Analysis and Prevention, 104, 106114. https://doi.org/10.1016/i.aap.2017.04.023

Van de Ven, B., van den Tooren, M., \& Vlerick, P. (2013). Emotional job resources and emotional support seeking as moderators of the relation between emotional job demands and emotional exhaustion: A twowave panel study. Journal of Occupational Health Psychology, 18(1), 1-8. https://doi.org/10.1037/a0030656

van der Ploeg, E., \& Kleber, R. J. (2003). Acute and chronic job stressors among ambulance personnel: predictors of health symptoms. Occupational and Environmental Medicine, 60(suppl 1), 40-46. https://doi.org/10.1136/oem.60.suppl_1.i40

Williamson, A. M., \& Feyer, A. M. (2000). Moderate sleep deprivation produces impairments in cognitive and motor performance equivalent to legally prescribed levels of alcohol intoxication. Occupational and Environmental Medicine, 57(10), 649-655. https://doi.org/10.1136/oem.57.10.649 
